\title{
Two new biting midges from Pará, Brazil (Diptera: Ceratopogonidae)
}

\author{
Rosimeire Lopes da Trindade 1 , Maria Luiza Felippe-Bauer ${ }^{2}{ }^{+}$ \\ ${ }^{1}$ Coordenação de Zoologia, Entomologia, Museu Paraense Emílio Goeldi, Belém, PA, Brasil ${ }^{2}$ Laboratório de Diptera, \\ Instituto Oswaldo Cruz-Fiocruz, Av. Brasil 4365, 21040-900 Rio de Janeiro, RJ, Brasil
}

Two new species of Culicoides Latreille of the subgenus Haematomyidium Goeldi are described and illustrated based on female specimens from Pará, Brazil. The new species are compared with their similar congeners.

Key words: Culicoides (Haematomyidium) jurutiensis sp. nov. - Culicoides (Haematomyidium) martyrius sp. nov. neotropical bloodsucking midges - Pará - Brazil

During entomological surveys in the municipalities of São Geraldo do Araguaia and Juruti, Pará (PA), Brazil, female specimens of Culicoides belonging to two undescribed species of the subgenus Haematomyidium Goeldi were collected.

The purpose of this paper is to describe and illustrate these new species from Northern Brazil and make a discussion with related species of the subgenus Haematomyidium. Revisions in this subgenus for the Neotropics were made for the debilipalpis species group (Vitale et al. 1981) and for the paraensis species group (Wirth \& Felippe-Bauer 1989, Felippe-Bauer et al. 2003). According to Borkent and Spinelli (2007), 36 neotropical species are recognized in this subgenus.

Recently, Felippe-Bauer and Spinelli (2009) considered Culicoides bachmanni Spinelli as a junior synonym of Culicoides horticola Lutz. With this taxonomy update and the addition of the two new species described here, there are now from this subgenus 37 species from the Neotropical Region, being 18 known from Brazil and 11 from the Amazonian Region.

\section{MATERIALS AND METHODS}

The specimens described herein as a new species were collected by CDC light trap in São Geraldo do Araguaia and Juruti, PA. The specimens were mounted in phenol-balsam in the manner described by Wirth and Marston (1968). The types were deposited in the Invertebrate Collection of the Emílio Goeldi Paraense Museum (MPEG), PA, and in the Ceratopogonidae Collection of the Oswaldo Cruz Institute (CCeIOC), Rio de Janeiro. Diagnostic characters were illustrated using a camera lucida attached to an Olympus BH-2 miscroscope. Microphotographies of the wings were taken with a Nikon Eclipse E-800.

In this paper, we follow the terminology established in Culicoides papers by Spinelli et al. (2005). Terms for wing veins follow the system of the Manual of Nearc-

Financial support: CNPq, ALCOA-Omnia Minérios

+ Corresponding author: mlfbauer@ioc.fiocruz.br

Received 14 June 2010

Accepted 4 August 2010 tic Diptera (McAlpine et al. 1981), with modifications proposed by Szadziewski (1996). The measurements of the spermathecae are in micrometers and those of the wings are in millimeters. Meristic information is given as range, following by the mean and number of specimens examined.

\section{Culicoides (Haematomyidium) jurutiensis, sp. nov.} (Figs 1-7)

Diagnosis - Only species in the subgenus Haematomyidium with two pale spots in cell $\mathrm{r} 3$ and $\mathrm{m}_{1}$ hairy eyes and moderately separated, head and proboscis nearly similar in length, moderately long palpus, subequal spermathecae, mandible with 17-18 teeth.

Female - Wing length $0.84 \mathrm{~mm}(\mathrm{n}=2)$, width $0.38 \mathrm{~mm}(\mathrm{n}=2)$.

Head: dark brown. Eyes (Fig. 2) separated by distance equal to diameter of 1.5 ommatidia, with numerous interommatidial spicules. Flagellum (Fig. 3) brown, with proximal 2/3 of flagellomeres 1-6 paler, flagellomeres elongate, vasiform; AR 0.85; sensilla coeloconica on flagellomeres $1,6-8$, one on 1 , two on 6, three on 7-8. Palpus (Fig. 5) dark brown; third segment swollen distally, with subapical shallow, rounded pit; PR $2.7(\mathrm{n}=2)$; PH ratio 0.91-1.00 $(0.95, \mathrm{n}=2)$. Mandible with 17-18 teeth.

Thorax: dark brown. Mesonotum without distinct pattern in slide mounted specimens. Legs (Fig. 7) dark brown, fore and midfemur with subapical and all tibiae with subbasal pale bands, narrow apex of hind tibia pale; hind tibial comb with four spines (Fig. 6), the two nearest the spur longest, subequal. Wing (Fig. 1) brownish infuscated, with only moderately distinct pattern of pale spots; second radial cell in dark spot; pale spot at crossvein $\mathrm{r}-\mathrm{m}$ abutting costal wing margin; poststigmatic pale spot in cell $\mathrm{r}_{3}$ slightly obliquely, distal pale spot in cell $\mathrm{r} 3$ transverse not abutting wing margin; $\mathrm{m}_{1}$ with two pale spots, the proximal smaller, rounded; distal one far from wing margin; $m_{2}$ with a faint pale spot posterior to medial fork; distal pale spots in $\mathrm{m}_{2} \mathrm{CuA}_{1}$ and anal cell abutting wing margin. Macrotrichia sparse, distributed on distal half of wing. CR 0.58-0.60 $(0.59, \mathrm{n}=2)$. Halter dark brown, stem pale. 
Abdomen: dark brown. Two ovoid, subequal spermathecae with short necks (Fig. 4), measuring 40 by $29 \mu \mathrm{m}$ and 35 by $27 \mu \mathrm{m}(\mathrm{n}=1)$ respectively; elongate, slender 3rd spermatheca $(32 \mu \mathrm{m})$ and short sclerotized ring also present.

Male - Unknown.

Types - Holotype female, área de beneficiamento do café, $02^{\circ} 29.535^{\prime} \mathrm{S} 56^{\circ} 09.334^{\prime} \mathrm{W}, 13-14$.XII.2007,

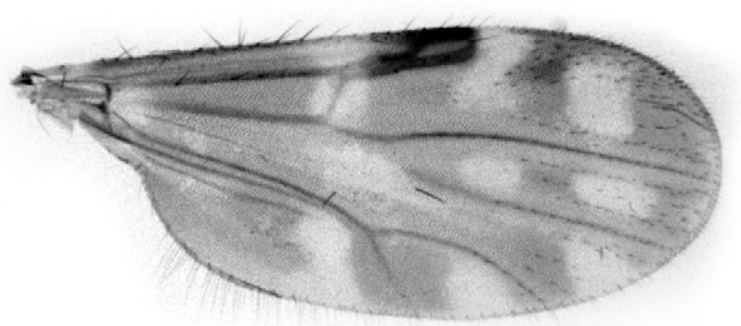

Fig. 1: wing photograph of Culicoides (Haematomyidium) jurutiensis sp. nov., female.
CDC light trap, RL Trindade, DDR Guimarães cols. (MPEG); paratype female, Juruti, Projeto Alcoa, comunidade do café torrado, Faz. Rezende, Forest, CDC light trap, 06-07.IV.2008, DDR Guimarães, E Monteiro \& A Quaresma cols. (CCeIOC 439).

\section{Distribution - Brazil (PA).}

Etymology - This species is named after the type locality.

Taxonomic discussion - C. jurutiensis is a typical member of the subgenus Haematomyidium. The wing pattern is very similar to Culicoides aragaoi Tavares \& Luna Dias from which it can be distinguished by the smaller wing length $0.84 \mathrm{~mm}(1.30 \mathrm{~mm}$ in $C$. aragaoi $)$, PR 2.7 (3.9 in aragaoi) and $\mathrm{P} / \mathrm{H}$ ratio 0.95 (1.20 in aragaoi). The new species has numerous interommatidial spicules (eyes bare in C. aragaoi).

Culicoides (Haematomyidium) martyrius, sp. nov.

(Figs 8-14)

Diagnosis - Species easily distinguished from the other species of the subgenus Haematomyidium by the
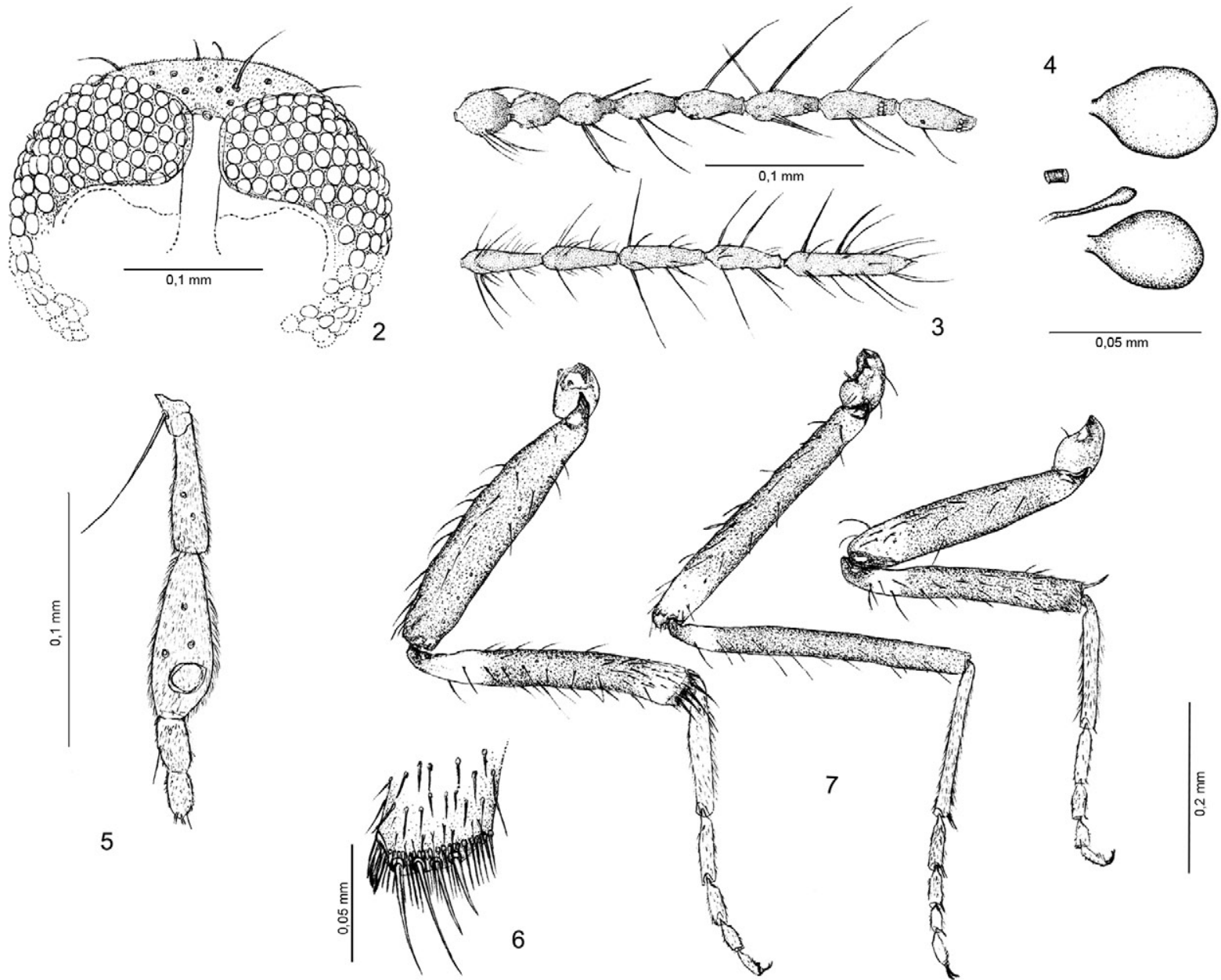

3

$0,05 \mathrm{~mm}$

5

6

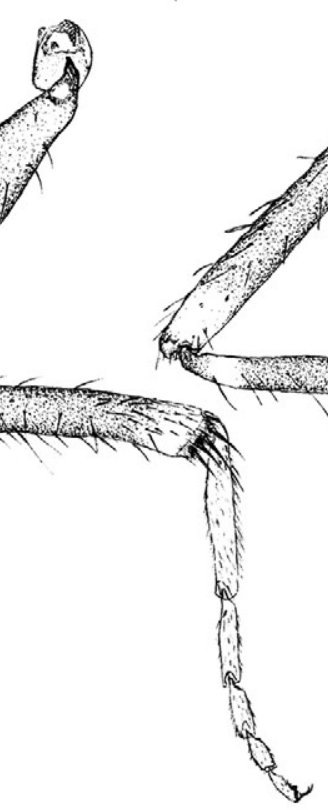

Figs. 2-7: Culicoides (Haematomyidium) jurutiensis sp. nov., female; 2: dorsal portion of head capsule, in anterior view; 3: flagellomeres 1-13; 4: spermathecae, 3rd psermatheca and sclerotized ring present; 5: palpus; 6: hind tibial comb; 7: legs (left to right) hind, mid and fore. 
single poststigmatic pale spot in cell $\mathrm{r}_{3}$ eyes bare and slightly separated, palpus moderately long with a shallow pit, fore-mid femur with a faint, irregular subapical pale bands, hind tibia without pale band in apical portion, unequal spermathecae.

Female - Wing length $0.89 \mathrm{~mm}$; breadth $0.40 \mathrm{~mm}$.

Head: brown. Eyes (Fig. 9) separated by distance equal to diameter of $1 / 2$ ommatidium, bare. Flagellum

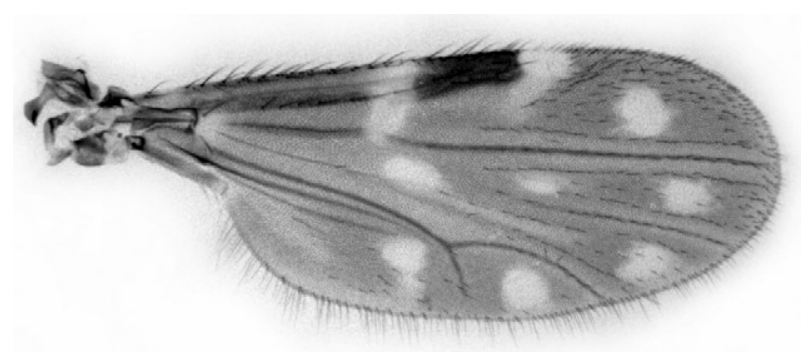

Fig. 8: wing photograph of Culicoides (Haematomyidium) martyrius sp. nov., female.
(Fig. 10) uniformly brown, flagellomeres short, vasiform; AR 0.80; sensilla coeloconica on flagellomeres 1, 6-8, one on 1, two on 6-8. Palpus (Fig. 12) brown, third segment swollen on mid length, with subapical shallow, rounded pit; PR 2.4; PH ratio 0.84. Mandible with 15 teeth.

Thorax: dark brown. Mesonotum without distinct pattern in slide mounted specimen. Legs (Fig. 13) brown, fore and midfemur with a faint, irregular subapical pale bands, tibiae with subbasal narrow pale bands, hind tibial comb with four spines (Fig. 14), the two nearest the spur longest, subequal. Wing (Fig. 8) brownish infuscated, with distinct pattern by definite, rounded pale spots; second radial cell in dark spot; pale spot at crossvein r-m abutting costal wing margin; poststigmatic pale spot in cell $\mathrm{r}_{3}$ extending indistinguishable beyond 2nd radial cell, distal pale spot in cell $r_{3}$ small, located in center of cell; $\mathrm{m}_{1}$ with two pale spots, the distal one larger than first, far from wing margin; $\mathrm{m}_{2}$ with two pale spots, one lying to medial fork, the distal one near wing margin; distal pale spots in $\mathrm{CuA}_{1}$ and anal cell not abutting wing margin. Macrotrichia present on distal half of wing, few in anal cell; CR 0.55. Halter pale brown, stem pale.
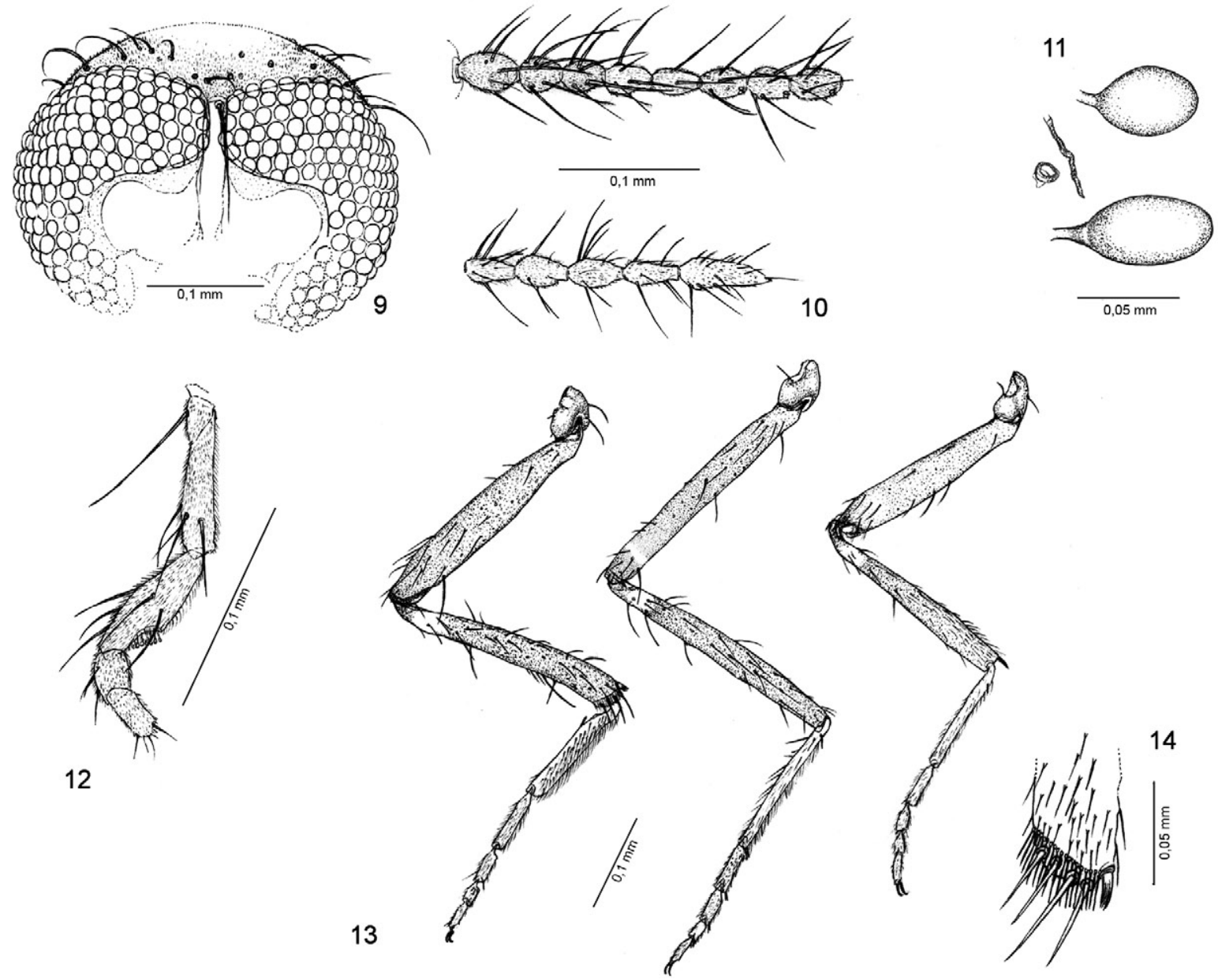

Figs. 9-14: Culicoides (Haematomyidium) martyrius sp. nov., female; 9: dorsal portion of head capsule in anterior view; 10: flagellomeres 1-13; 11: spermathecae, 3rd psermatheca and sclerotized ring present; 12: palpus, lateral view; 13: legs (left to right) hind, mid and fore; 14: hind tibial comb. 
Abdomen: brown. Two ovoid, distinctly unequal spermathecae with long necks $(13 \mu \mathrm{m})$ (Fig. 11), measuring 64 by $35 \mu \mathrm{m}$ and 48 by $35 \mu \mathrm{m}$, respectively; long, slender 3rd spermatheca $(40 \mu \mathrm{m})$ and short, round sclerotized ring also present.

Male - Unknown.

Type - Holotype female, Brazil, São Geraldo do Araguaia, Serra dos Martírios-Andorinhas, 16.X.2005, 17:00 pm, biting human, B. Mascarenhas col. (MPEG).

Distribution - Brazil (PA).

Etymology - This species is named after the type locality.

Taxonomic discussion - C. martyrius is a member of the subgenus Haematomyidium. It has wing pattern similar to Culicoides germanus Macfie, from which it can be distinguished by its slightly longer wing $0.89 \mathrm{~mm}(0.80$ in C. germanus), greater PR 2.4 (2.0 in C. germanus), by the single poststigmatic pale spot (double in $C$. germanus), fore-mid femur with subapical pale bands (dark femurs in C. germanus) and by the apical portion of hind tibia dark (with broad pale area in C. germanus).

\section{ACKNOWLEDGEMENTS}

To Tiago do Nascimento da Silva, for the confection of the figures, to Rodrigo Mexas, for assistance in the wing photographs and plates of figures, to Dr Bento Mascarenhas, for sent us part of the material studied, to Drs Orlando Tobias Silveira and Inocêncio S Gorayeb, for providing logistic support, and to Domingos Guimarães, Emerson Monteiro and Luis A Quaresma, for assistance in the field works in Juruti, PA.

\section{REFERENCES}

Borkent A, Spinelli GR 2007. Neotropical Ceratopogonidae (Diptera: Insecta). In J Adis, JR Arias, G Rueda-Delgado, KM Wantzen, Aquatic biodiversity in Latin America (ABLA), vol. IV, Pensoft, Sofia, p. 1-198.

Felippe-Bauer ML, Cáceres AG, Silva CS, Valderrama-Bazan W, Gonzales-Perez A 2003. Two new Culicoides of the paraensis species group (Diptera: Ceratopogonidae) from the Amazonian region of Peru. Mem Inst Oswaldo Cruz 98: 1051-1058.

Felippe-Bauer ML, Spinelli GR 2009. New records, synonymy and description of the male of Culicoides horticola Lutz, 1913 (Diptera: Ceratopogonidae). Biota Neotrop 9: 27-30.

McAlpine JF, Peterson BV, Shewell GE, Teskey HJ, Vockeroth JR, Wood DM 1981. Manual of Nearctic Diptera, Agriculture Canada, vol. I, Monograph 27, Biosystematic Research Institut, Otawa, 674 pp.

Spinelli GR, Ronderos MM, Díaz F, Marino PI 2005. The bloodsucking biting midges of Argentina (Diptera: Ceratopogonidae). Mem Inst Oswaldo Cruz 100: 137-150.

Szadziewski R 1996. Biting midges from Lower Cretaceous amber of Lebanon and Upper Cretaceous Siberian amber of Taimyr (Diptera: Ceratopogonidae). Studia Dipterol 3: 23-86.

Vitale GC, Wirth WW, Aitken THG 1981. New species and records of Culicoides reared from arboreal habitats in Panama, with a synopsis of the debilipalpis group (Diptera: Ceratopogonidae). Proc Entomol Soc Wash 83: 140-159.

Wirth WW, Felippe-Bauer ML 1989. The neotropical biting midges related to Culicoides paraensis (Diptera: Ceratopogonidae). Mem Inst Oswaldo Cruz 84 (Suppl. IV): 551-565.

Wirth WW, Marston N 1968. A method for mounting small insects on microscope slides in Canada Balsam. Ann Entomol Soc Am 61: 783-784. 